\title{
Sosyal Yargı Kuramı Perspektifinde Genç \\ Tüketicilerin Davranışsal Niyetlerinin Oluşumunda İlgilenim Düzeylerinin Etkisi
}

\section{Emine ŞENBABAOĞLU DANACI ${ }^{1}$ Nurettin PARILTI ${ }^{2}$}

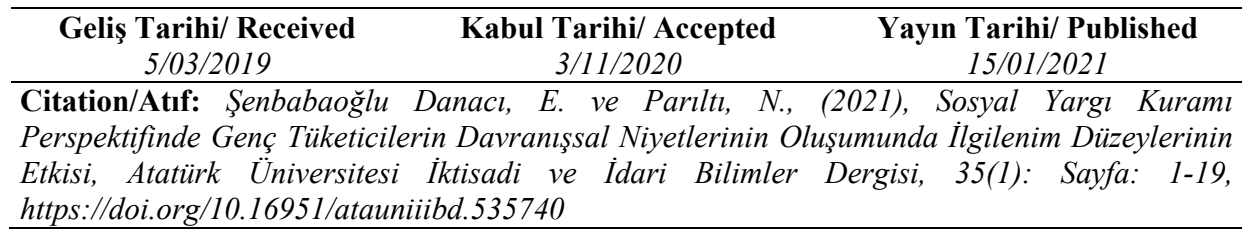

Öz: Bu çalışmanın amacı, Nedenli Eylem Teorisi (TRA) ve Teknoloji Kabul Modeli (TAM) kapsamında ele alınan tutum-niyet ve davranış modelinden de hareket edilerek satın alma davranışının öncüsü olan niyet üzerinde ilgilenimin etkisini ortaya koymaktır. Bu çalışma Sosyal Yargı Teorisine dayandırılmaktadır. Çalışma kapsamında ilgilenim; ilgi, hedonik değer, sembolik değer, algılanan risk ve hata olasılığı olmak üzere beş boyutlu bir şekilde ele alınmaktadır. Çalışmada, ilgilenim ölçeğinde yer alan boyutların ayrı ayrı davranışsal niyete olan etkileri ölçülmektedir. AMOS ve SPSS paket programları kullanılarak kurgulanan araştırma modeli analiz edilmiştir. Bu çalışmanın temel bulgusu, genç tüketicilerin ilgilenim düzeylerinin, davranışsal niyet oluşumları üzerinde etkili olmasıdır.

Anahtar Kelimeler: Sosyal Yarg1 Kuramı, Nedenli Eylem Teorisi, Teknoloji Kabul Modeli, İlgilenim, Davranışsal Niyet.

\section{The Effect Of Involvement Levels on the Formation of Behavioral Intentions of Young Consumers in the Social Judgment Theory Perspective}

Abstract: The purpose of this study demonstrate the effect of involvement on the intention, which is the pioneer of buying behavior, by acting on the attitude-intention-behavior model based on Theory of Reasoned Action (TRA) and Technology Acceptance Model (TAM). This study is based on the Social Judgment Theory. Involvement was addressed in five dimensions, interest, symbolic value, hedonic value, perceived risk and probability of error. In this study, the effects of individual dimensions of the scale of involvement on behavioral intention are measured. The research model constructed using AMOS and SPSS package programs was analyzed. The main finding of this study is that the level of interest of young consumers influences behavioral intentions.

Keywords: Social Judgment Theory, Theory of Reasoned Action (TRA), Technology Acceptance Model (TAM), Involvement, Behavioral Intention.

\footnotetext{
${ }^{1}$ Arş. Gör. Dr., Düzce Üniversitesi, İşletme Fakültesi, İşletme Bölümü, https://orcid.org/00000002-8402-5904

${ }^{2}$ Prof. Dr., Ankara Hacı Bayram Veli Üniversitesi, İİBF, İşletme Bölümü, https://orcid.org/0000$\underline{0002-2811-6174}$
} 
Sosyal Yargı Kuramı Perspektifinde Genç Tüketicilerin Davranışsal Niyetlerinin Oluşumunda Ilgilenim Düzeylerinin Etkisi

\section{Background}

\section{EXTENDED SUMMARY}

This study, which is based on the theory of social judgment, was designed based on the views that the behaviors of consumers will occur in parallel with their level of involvement. According to the social judgment theory, individuals' judgments take shape by changing according to their personal situation. The factor under study in theory is involvement. The need to examine the level of involvement in studies analyzing the attitudes and behaviors of individuals leads to the necessity of examining the levels of involvement in the analysis of consumer attitudes and behaviors. Consumers' level of involvement is not expected to be the same. Consumer behavior is expected to differ according to the level of interest and importance given to the product by individuals.

\section{Purpose}

The aim of this study is to examine the effect of young consumers' levels of involvement in smartphones on their behavioral intentions. Based on the attitude-intention and behavior model considered within the scope of Theory of Reasoned Action (TRA) and Technology Acceptance Model (TAM), it is to reveal the effect of involvement on intention, which is the pioneer of purchasing behavior. In this study, it was investigated whether the dimensions of involvement have an effect on the formation of behavioral intentions of consumers.

\section{Method}

Data were collected from the population of the study, which consisted of Gazi University students, using the convenience sampling method. A face-toface questionnaire was conducted with the students selected by the easy sampling method. Cronbach's Alpha reliability coefficients were determined primarily for the reliability test of the scales used in this study, in which the effect of involvement towards smart phones on the formation of behavioral intention of a group of university students, defined as young consumers, was examined. Explanatory Factor Analysis (EFA) and then Confirmatory Factor Analysis (DFA) were performed with the help of SPSS 22 and AMOS 23 package programs. Regression analysis was used to test the hypotheses.

\section{Findings}

In this study, in which the effect of consumer involvement levels on behavioral intentions was examined, the effects of the involvement variable on behavioral intention formation in its five-dimensional form, which is commonly included in the literature, were measured separately. After the analysis, interest, hedonic value and symbolic value, which are among the dimensions of involvement, positively; Perceived risk and error probability dimensions were found to have the greatest effect on shaping consumers' intentions negatively. 


\section{Conclusions}

Two important concepts in consumer behavior are involvement and behavioral intention. This study supported the relationship between the two factors. As a result of this study, which was designed based on the fact that interest levels will have an effect on the formation of consumers' behavior, it has been concluded that as the interest levels of consumers increase, behavioral intent formation will strengthen.

The smart phone used the study is a product of high involvement level. If practitioners want to be effective in the purchasing process of consumers, they should act in line with the effect of consumer interest, which is discussed together with its sub-dimensions in this study, on forming behavioral intention.

With this study carried out for young consumers and smart phones, interest, hedonic value and symbolic value are positive; It shows the perceived risk and probability of error and the negative effects on behavioral intention.

In the smartphone market, by reducing the perceived risk level and the probability of error for the products of the practitioners; It is supported by the results of the study that young consumers need to develop marketing strategies in line with increasing their perceptions of interest, hedonic values and symbolic values.

\section{Giriş}

Sosyal yargı teorisine dayandırılan bu çalışma, tüketicilerin sergiledikleri davranışlar, ilgilenim düzeyleri ile paralel doğrultuda oluşacağına dair görüşlerden hareketle tasarlanmıştır. Sosyal yarg1 teorisine göre bireylerin yargıları, içinde bulundukları kişisel durumlarına göre değişime uğrayarak şekil almaktadır. Teori kapsamında incelenen faktör ilgilenimdir. İlgilenim, tüketicilerin karar alma ve iletişim davranışlarında etkili olan bir değişkendir. İlgilenim kavramının, algılanan risk, bilgi arayışı, marka sadakati, marka benzerliği, fikir liderliği, marka değiştirme ve reklam olmak üzere birçok pazarlama kavramıyla ilişkilendirildiği ilgili yazında görülmektedir.

İlgilenim kavramının ortaya çıkışı, sosyal psikoloji ve özellikle ikna edici iletişim literatürüne dayandırılmaktadır. Sosyal yargı ve ilgilenim yaklaşımları, tutum ve tutumdaki değişimi açıklamakla birlikte ele alınmaktadır (Michaelidou ve Dibb, 2008: 3). Sosyal yarg1 teoricileri, ilgilenim düzeyinin oluşumunda, tutumların ortaya çıkışı ile bağlantı kurmuşlardır. Devamlı olarak yeni özelliklere sahip ürünlerin tüketicilere sunulduğu ve oldukça yoğun rekabetin yaşandığı günümüz akıllı telefon pazarında, üreticilerin tüketici davranışlarına hâkim olması gerekmektedir. Bu doğrultuda hem fiziksel hem de bilgi ortamlarına dâhil edilen aygitlar olarak nitelenen akıllı telefonlar (López vd., 2011), ilgilenim düzeyiyle yüksek oranda ilişkili olması sebebiyle araştırmanın uygulama bölümünde kullanılmıştır.

$\mathrm{Bu}$ çalışmanın amacı, genç tüketicilerin akıllı telefonlara olan ilgilenim düzeylerinin davranışsal niyetlerine olan etkisini incelemektir. Bir diğer 
Sosyal Yargı Kuramı Perspektifinde Genç Tüketicilerin Davranışsal Niyetlerinin Oluşumunda Illgilenim Düzeylerinin Etkisi

ifadeyle, bu çalışmada ilgilenimin boyutlarının, tüketicilerin davranışsal niyetlerinin oluşumunda etkisinin olup olmadığı araştırılmıştır. Çalışmada ilk olarak sosyal yargı kuramı detaylandırılmıştır. Ardından davranışsal niyet oluşumu ve ilgilenim kavramı ifade edilmiştir. Çalışma kapsamında varsayılan hipotezler nedenleriyle birlikte ortaya koyulurken, hipotezlerden oluşan araştırmanın yapısal modeli test edilmiştir. Hem ilgili literatüre hem de uygulamaya dönük ortaya çıkan katkılara yer verilmiştir. Takiben de öneri ve kısıtlar çalışmaya dahil edilmiştir.

\section{Literatür İncelemesi}

\subsection{Sosyal Yargı Kuramı}

Sosyal yarg1 kuram1, Sherif vd. (1967) tarafindan ortaya atılan bir teoridir. Bu teori kapsamında bireylerin tutumlarının ilgilenim düzeylerine göre şekillendiği savunulmaktadır. Literatürde yer alan bir diğer kaynakta sosyal yarg1 kuramı, bireylerin zaten var olan bildikleri ve hissettikleri şeylerin ışığında tutumlarını yeni bilgiler ile özümseyebilmeleri şeklinde ifade edilmektedir (Solomon vd., 2006: 149). Sosyal yarg1 teorisi, bireylerin yargılarına dönük genel bir çerçeve çizmektedir (Brehmer, 1988: 13). Ostrom ve Brock (1968) da teoriye dönük yaptıkları çalışmalarında ilgilenim düzeyinin, tutum ile ilişkisinin olduğunu ileri sürmüşlerdir. Sosyal yarg1 teorisinde, bireylerin yargılarının çevreden algılanan bilgilerin farklı ipuçları ve kaynaklarla bütünleştirilmesine dayandığı varsayılmaktadır (Cooksey, 1996: 141). Yine Cooksey (1996: 141)'e göre sosyal yarg1 teorisi, belirli bir çevre bağlamında incelenerek bireylerin yargılarını anlamak için bir bakış açısı veya bir metodoloji olarak 1960'lı ve 1970'li yıllarda ortaya atılmıştır (Cooksey, 1996: 141).

Sosyal yargı teorisinin, tüketicilerin karar almalarında sosyal bir süreç olduğu savunulmaktadır (Dhir, 1987: 150). Teorinin öne sürdüğü görüşlerden birisi, bireyler kabul edilebilir ya da kabul edilemez bilgi elde etme yoluyla farklılaşabilmektedir (Solomon vd., 2006: 149). Sosyal yarg1 teoricileri, ilgilenim düzeyi ile tutumların ortaya çıkışı arasında bağlantı kurmuşlardır. Tüketiciler karar alırken pazardaki sosyal etkileşimden etkilenmektedir (Dhir, 1987: 150). Leckie vd. (2016)'ne göre de sosyal yarg1 teorisi, tüketicilerin önceki değer yargılarına dayanarak tutum sergilemeleridir.

Sosyal yarg1 teorisi, hukuka yönelik bir teori değildir. Sosyal yarg1 teorisyenleri, beşeri yargı adına bilişsel destek yaratma ile ilgilenmektedirler (Hammond vd., 1975: 276). Bireylerin bilişsel sistemlerinin analizinde olmak üzere yarg1 probleminin tanımlanması, yargının incelenmesi, yargının analiz edilmesi ve sonuçların sergilenmesi şeklinde dört adımdan bahsedilmektedir (Hammond vd., 1975: 277).

Temel olarak sosyal yargı teorisine dayandırılan bu çalışmaya, değişkenlerin ortaya koyulabilmesi açısından literatürde sıklıkla yer verilen iki teori kapsamında genişletilerek devam edilmişsir. Bunlardan ilki olan Nedenli 
Eylem Teorisi (TRA), tutum, davranış ve niyet arasındaki ilişkiyi incelemek için Fishbein (1967) tarafindan geliştirilmiştir (Montaño ve Kasprzyk, 2008). Fishbein ve Ajzen (1975) nedenli eylem teorisinde niyeti, davranışı sergileyecek kişinin söz konusu davranışı olumlu ya da olumsuz olarak değerlendirmesini davranışa yönelik tutum; kişinin bir davranışı gerçekleştirip gerçekleştirmemeye ilişkin algıladığı sosyal baskıyı ise öznel norm olarak iki bileşende belirlemişlerdir (Fishbein ve Ajzen, 1975).

Bir diğeri ise Teknoloji Kabul Modeli (TAM), Davis tarafindan 1989 yılında ortaya atılan algılanan kullanışlılık ve algılanan kullanım kolaylığının tutuma, tutumunda niyet ve davranışa olan etkisini ortaya koymak üzere tasarlanan bir modeldir. Çevresel değişkenler arasındaki belirsizliklerden, karmaşık ilişkilerden dolayı çevreden bilgiye ulaşmak çok kolay değildir (Hammond vd., 1975: 272). Bu doğrultuda sosyal yargı teorisi kapsamında ele alınan tutum faktörünün ölçülmesi, TRA ve TAM modelinden hareketle davranışsal niyete yönlendirmektedir. Tüketici niyetlerinin şekillenmesinde tutumlar etkili olmaktadır. Bu doğrultuda çalışmada tutum-niyet-davranış olgusunda davranışa daha yakın bir faktör olarak karşımıza çıkan davranışsal niyet ölçümü tercih edilmiştir.

\subsection{Davranışsal Niyet Oluşumu}

$\mathrm{Bu}$ bölümde ilk olarak tutumdan hareket edilerek davranışsal niyete nasıl ulaşıldığına yer verilmiştir. Ardından bu görüş Nedenli Eylem Teorisi ve Teknoloji Kabul Modeli doğrultusunda açıklanmıştır. Sosyal psikoloji alanında siklıkla yer verilen kavramlardan biri tutumdur. Bireyin bir olaya yönelik tutumu, amaçlara ulaşmak için devamlı olarak sergilenen olumlu ya da olumsuz tavır ve eğilim olarak ifade edilmesi genel kabul görmektedir (Fishbein ve Ajzen, 1974). Fishbein (1967) çalışmasında davranışa yönelik ve amaca yönelik tutumu ayrı olarak ele almıştır. Fishbein ve Ajzen (1975) daha sonra yaptıkları çalışmalarında ise davranışa yönelik tutumun incelenmesinin davranışın gerçekleşmesinde daha etkili olduğunu ortaya koymuştur (Montaño ve Kasprzyk, 2008). Ajzen ve Fishbein (1977)'in tutum ve davranış arasındaki benzeşmeyi inceledikleri çalışmada davranış ve tutumun; davranışın türü, davranışın amacı, davranışın sergilendiği ortam ve davranışın sergilendiği zaman olmak üzere, bu dört unsurdan oluştuğu kabul edilmektedir. Davranışın şekillenmesinin önemli belirleyicilerinden olan tutum, davranışla ne kadar benzeşiyorsa aralarındaki ilişki o kadar güç kazanmaktadır (Ajzen ve Fishbein, 1977: 905).

Tutum, bireylerin davranışsal inançları ile belirlenmektedir. Bir kişi davranışın sergilenmesine neden olan inançlarını güçlü tutarsa davranışa yönelik pozitif tutuma sahip olacak ve davranışın gerçekleşmesini kolaylaştıracaktır. Aksi düşünüldüğünde de kişi inançlarını negatif yönde tutarsa, negatif yönlü tutum ve davranışın sergilenmesine neden olacaktır (Montaño ve Kasprzyk, 2008: 71). 
Sosyal Yargı Kuramı Perspektifinde Genç Tüketicilerin Davranışsal Niyetlerinin Oluşumunda Illgilenim Düzeylerinin Etkisi

Genel olarak tutum, bireyin çevresindeki herhangi bir konuya (canlı ya da cansız) karşı sahip olduğu bir tepki eğilimini ifade etmektedir. Tutum kavramı, psikoloji ve sosyolojiyi birleştiren disiplinler arası bir kavramdır. Bu bağlamda bireylerin tutumları, oluşum ve konuları açısından sosyal kaynaklıdır; ancak aynı zamanda, bireyin psikolojik yapısı ve davranışının da bir parçasıdır (Baysal, 1981: 121). Baysal (1981: 123) çalışmasında tutumlar ile davranışlar arasında eş yönde ilişki olduğuna işaret ederek yapılan birçok çalışmada da bu durumun kanıtlanmaya çalışıldığını savunmaktadır.

Çalışmanın daha önceki bölümlerinde üzerinde durulan Teknoloji Kabul Modeli (TAM) ve Nedenli Eylem Teorisinden (TRA) hareketle tutumların davranışsal niyetleri şekillendireceği varsayımına dayanarak çalışmada davranışsal niyet ölçümü gerçekleştirilmiştir. Sığındı ve Kavak (2015) kolayda, beğenmeli ve özellikli ürün ayrımıyla yaptıkları çalışmada tüm bu ürün sinıflamalarına ait tutumun satın alma niyetine olan etkisini ortaya koymuşlardır. Literatürde davranışsal niyete dair kullanılan yaygın ifade; tutum ve davranış arası bir yerde olmasıdır (Mittal ve Kamakura, 2001). Zeithaml vd. (1996)'ne göre davranışsal niyet, müşterilerin hizmet işletmesi ile ilişkisini sağlamlaştırdığının göstergesidir. Bir başka ifadeyle, davranışsal niyet müşterilerin işletmeden hizmet sağlamaya devam etme ya da işletmeyi terk etmelerinin göstergesidir (Lin ve Hiesh, 2007). Müşterilerin davranışları niyetlerinden tahmin edilebilme olasılığı olduğu için (Bai vd., 2008: 394) müşterilerin satın alma niyetlerini anlamak bu noktada önemlidir. Her ne kadar bireylerin karar verme süreçlerini tam anlamıyla tanımlamak pek mümkün olmasa da (Dhir, 1987: 150) davranışsal niyet tüketici davranışlarını anlamak açısından önemli bir faktördür (Kaur ve Gupta, 2012).

\subsection{Illgilenim}

İlgilenim, pazarlama ve tüketici araştırmaları kapsamında sıklıkla incelenen bir faktördür. İlgilenimin akademik ve araştırmacılar için değerine ilaveten, uygulayıcılar için de dikkate alınan önemsenen çok boyutlu bir faktör olduğu savunulmaktadır (Michaelidou ve Dibb, 2008: 2). İlgilenim, kişinin değer ve ihtiyaçlarının belirleyici faktörlerine dayanan motivasyonel bir yapı olarak ifade edilebilmektedir (Zaichkowsky, 1994: 59-70). İlgilenim, bireylerin var olan ihtiyaç, değer ve ilgilerine dayanan objelere duyduğu ilgi olarak tanımlanmaktadır. Burada obje kelimesi, genel bir duygu ya da bir ürün (ya da bir marka), bir reklam ya da satın alma durumu için kullanılmaktadır. Tüketiciler, tüm bu objelere dönük ilgilenim sağlayabilirler (Solomon vd., 2006: 105). Tüketici davranışı bağlamında ilgilenim, tüketicinin ürünlere, reklamlara ve tüketim sürecinin farklı yönlerine kişisel ilgi veya yakınlığının göstergesidir (Eastman vd., 2014).

İlgilenim onu tetikleyen farklı öncülleri olan motivasyonel bir yapıdır. Bilgiyi yönlendirmek için motivasyon olarak kullanılan ilgilenim (Solomon vd., 2006: 106), Sherif vd. (1973)'ne göre ise ikna etme iletişimi olarak tanımlanmaktadır. Sosyal yargı kuramı üzerinde çalışanlar, ilgilenimi kişisel ilgi 
ve önem ya da güçlü, kalıcı tutumların ortaya çıkışı ile ilişkilendirmişlerdir (Ulusu, 2016: 570). Tüketici ilgilenimi kavramında araştırmalar, Sherif vd. (1973)'nin yaptıkları çalışmaya dayanmaktadır. Çoğu yazar bu kavramı, tüketici araştırmaları ve teorileri kapsamında incelemektedir (Laurent ve Kapferer, 1985: 41-42). Ayrıca ilgilenim, sosyal yarg1 teorisine dayandırıldığ için hipotetik ve spekülatif bir kavram olarak görülmektedir (Michaelidou ve Dibb, 2008: 5). Tüketicilerin belirli bir markaya yönelik ilgi ve odaklanma düzeyi arttıkça, bu markalara güçlü bir inanç duyma eğiliminde olacaklardır. İlaveten tüketicilerin bir ürün kategorisine olan ilgilenimleri, tercih edilen bir hizmet sağlayıcısının markasına olan tutumunu olumlu yönde etki sağlamaktadır (Leckie vd., 2016).

Tüm bu tanımlamalardan hareketle ilgilenim kavramına ilişkin literatürde çok çeşitli tanımlamaların mevcut olduğu görülmektedir. İlgilenim kavramının tanımlanmasına yönelik var olan bu çeşitlilik, ilgilenimi ölçmeye yarayan ölçek çeşitliliğine de yansımaktadır. Çalışmanın bu bölümünde literatürde mevcut olan ilgilenim ölçeklerine yer verilmiştir. Zaichkowsky (1985) tarafindan geliştirilen Kişisel İlgilenim Envanteri (PII), bireylerin ürünlere olan ilgilenimlerini ölçmek amacıyla geliştirilmiştir. Yirmi ifadeli tek boyutlu olan ölçek reklamlara, ürünlere ve satın alma kararlarına uygulanabilecek şekilde geliştirilmiştir.

Laurent ve Kapferer (1985) '’n beş boyuttan oluşan Tüketici İlgilenim Profili (CIP) adı verdikleri ilgilenim ölçeği, ilgilenime ilişkin bir diğer ölçektir. İlgilenimin çok boyutlu yapıda olduğunu savunarak hazırlanan bu ölçek, algılanan risk, hata olasılığı, sembolik değer, hedonik değer ve ilgi olmak üzere beş boyuttan oluşmaktadır. Çakır (2007) tüketici ilgilenimine yönelik ölçekleri derlediği çalışmasında, ilgili ölçeği ilgi, haz, gösterge, risk önemi ve hata olasılı̆̆ 1 olarak ifade etmiştir. Söz konusu ölçeği bir başka çalışmada, ilgi, hata olasılığı, risk önemi, sembolik değer ve hedonik değer olarak niteleyen Özbek ve Külahlı (2016) çalışmalarında, cinsiyete göre bu faktörlerde değişim olup olmadığını araştırmışlar ve farklı ürün gruplarında oluşan farklılıkları ortaya koymuşlardır.

Zaichkowsy (1985) 'nin Kişisel İlgilenim Envanteri (PII) ve Laurent ve Kapferer (1985) 'ın Tüketici İlgilenim Profili (CIP) ölçeklerinden yola çıkarak, ölçek geliştiren McQuarrie ve Munson (1986) risk-önem-haz olmak üzere üç boyutlu ve on altı ifadeli bir şekilde ele alarak Gözden Geçirilmiş Kişisel İlgilenim Envanteri (RPII)'ni geliştirmişlerdir. Sürekli ilgilenimi, tüketicilerin bir ürün veya aktiviteye yönelik, kişisel ilgi potansiyeli olarak tanımlayan ve tüketici davranışlarında sürekli ilgilenimin odaklanması gerektiğini vurgulayan Higgie ve Feick (1989: 690), Sürekli İlgilenim Ölçeği geliştirmişlerdir. Bu ölçek geçmiş araştırmalara dayanak gösterilerek haz ve kendini ifade etme boyutlarından ve on ifadeden oluşmaktadır. Ardından, Jain ve Srinivasan (1990) literatürdeki ilgilenim ölçeklerini harmanlayarak Yeni İlgilenim Profili (NIP) ölçeğini geliştirmişlerdir. Bu ölçek; gösterge, riskin önemi, risk ihtimali, haz ve 
Sosyal Yargı Kuramı Perspektifinde Genç Tüketicilerin Davranı̧ssal Niyetlerinin Oluşumunda Illgilenim Düzeylerinin Etkisi

ilgi olmak üzere beş boyut ve on beş ifadeden oluşan bir şekilde oluşturulmuştur.

Tüm bu ölçekler değerlendirildiğinde, bu çalışmada ilgili literatürde sıklıkla kullanılmış olan ve çalışmanın uygulama alanında kullanılacak olan akı1lı telefon ürününe yönelik uyarlanarak, ifadelerin anlaşılır olması nedeniyle Laurent ve Kapferer (1985) 'ın ilgi, hedonik değer, sembolik değer, algılanan risk ve hata olasılığ 1 olmak üzere beş boyuttan oluşan Tüketici ilgilenim Profili (CIP) ölçeği kullanılmıştır. Bu çalışmada Tüketici İlgilenim Profili (CIP) ölçeği kullanıldığ 1 için ölçekte yer alan boyutlara yer verilmesi uygun bulunmuştur. İlk olarak, ilgi kavramı bir ürün satın alırken hangi çeşit ya da hangi marka olduğuna önem verme, ürünün çeşitleri arasındaki farkları inceleme, doğru ürün seçiminin önemi, tercihlerin sonuçlarına ilişkin dikkat olarak ifade edilmektedir (Michaelidou ve Dibb, 2008: 15). Ölçeğin bir diğer boyutu olan hedonik değer, duygusal çekicilik ve istek veya arzularını karşılama noktasında karşılaşılan değerdir (Laurent ve Kapferer, 1985: 43). Sembolik değer ise, bir mal ya da hizmetin satın alınmasına veya onun tüketilmesine yönelik tüketiciler tarafından atfedilen değerdir. Sembolik değer, psikolojik riskten fonksiyonel riskin ayrıştırılmasıyla ortaya çıkar (Laurent ve Kapferer, 1985: 43). Arbore vd. (2014), sembolik değerin tüketicilerin ürüne yönelik atfettiği kişisel anlamla ilişkili olduğunu savunmuşlardır. Bu açıdan bakıldığında ürünler, bireyler ve taraflar arasındaki sembolik iletişim araçlarına hizmet eder. Bir ürünün sembolik değeri, sosyal ve kişisel önemini içeren anlamlardan doğan ifadelerdir (Arbore vd., 2014).

Algılanan risk, negatif ve subjektif bir duygudur. Algılanan riskin bazı aşamaları, dereceleri olsa da satın almaya dönük ilgilenim duygusunun gelişmesine katkı sağlar. Pazarlama uygulayıcıları, tüketiciler tarafından algılanan riskin azaltılması doğrultusunda girişimde bulunurlar. Bu durum ise satın alma kararına dönük ilgilenimin artmasına katkı sağlamaktadır (Mittal, 1989: 14). Algılanan riske göre davranışsal niyetin şekilleneceği düşünülmektedir. Tüketici ilgilenim profilinin bir diğer boyutu olan hata olasılığ ise, yanlış bir ürün seçme riski veya olasılığ 1 olarak ifade edilmektedir (Kapferer ve Laurent, 1993).

\section{Hipotezler, Araştırma Modeli ve Metodoloji}

\subsection{Hipotezler ve Arastırma Modeli}

İlgilenim düzeyi yüksek olan tüketiciler, tüketimin ötesinde ürün kategorisine yönelik bağlllık hissine sahip olmayı istemektedir (Leckie vd., 2016). Marka tutumu oluşumunda ilgilenimin etkisini ortaya koymak için yaptıkları çalışmada Park ve Young (1983), ilgilenimin hem bilişsel hem de duygusal bağlamda gerçekleştiğini vurgulamışlardır. Teoride ilgilenim, bireysel olarak farkl1lık gösteren değişken olarak düşünülmektedir. Tüketicilerin iletişim ve satın alma davranışlarında birkaç sonuç ortaya koyan nedenli davranışlardır. $\mathrm{Bu}$ yüzden, tüketicilerin satın alma karar süreçleri, yoğunlukla farklılaşma 
ilgilenim düzeylerine bağlı olarak gelişmektedir (Laurent ve Kapferer, 1985: 42).

İlgilenim ilgi, hedonik değer, sembolik değer, algilanan risk ve hata olasılığı olmak üzere beş boyutlu olarak çalışmada ele alınmıştır. Davranışsal niyet oluşumunda ilgilenimin boyutlarının etkisinin olup olmadığını görebilmek amacıyla aşağıdaki hipotezler oluşturulmuştur: etkilidir.

$\mathbf{H}_{1}$ : İlgilenimin boyutlarından olan ilgi, davranışsal niyetin oluşumunda

$\mathbf{H}_{2}$ : İlgilenimin boyutlarından olan hedonik değer, davranışsal niyetin oluşumunda etkilidir.

$\mathbf{H}_{3}$ : İlgilenimin boyutlarından olan sembolik değer, davranışsal niyetin oluşumunda etkilidir.

$\mathbf{H}_{4}$ : İlgilenimin boyutlarından olan algılanan risk, davranışsal niyetin oluşumunda etkilidir.

$\mathbf{H}_{5}$ : İlgilenimin boyutlarından olan hata olasılığı, davranışsal niyetin oluşumunda etkilidir.

Teorik olarak kurgulanan hipotezleri gösteren şekil, araştırma modeli olarak aşağıda sunulmuştur (Şekil 1).

\section{İlgilenim}

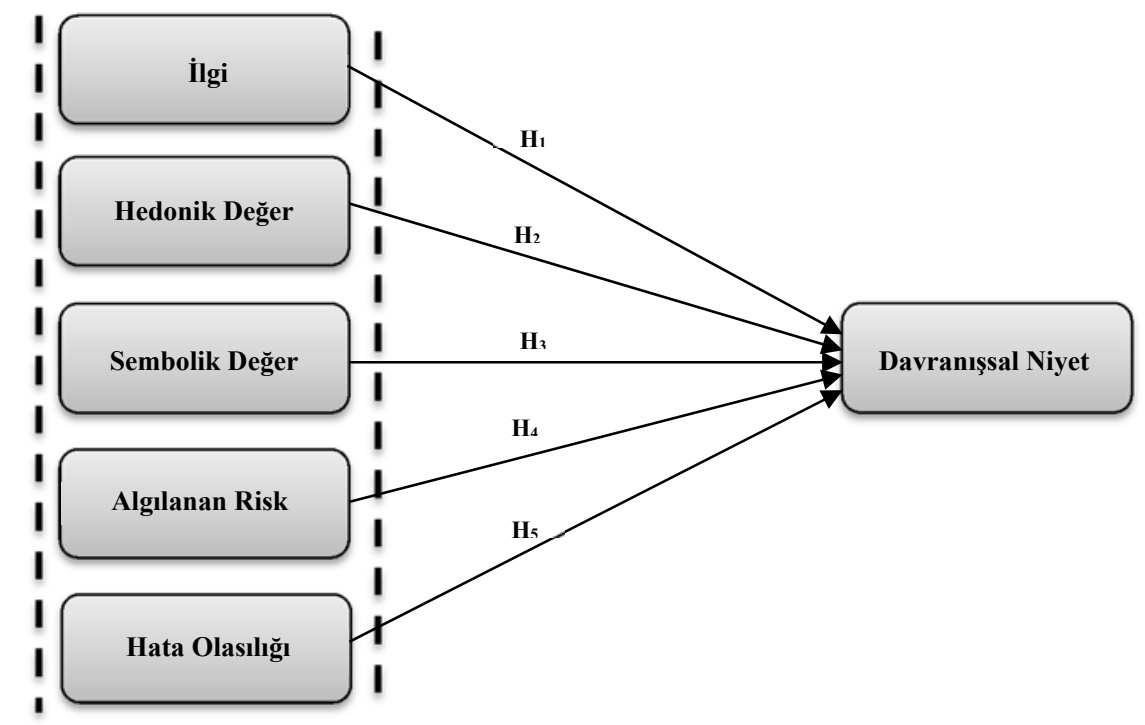

Şekil 1: Araştırmanın Hipotetik Modeli

\subsection{Metodoloji}

Gazi Üniversitesi İ̈BF öğrencilerinden oluşan araştırmanın ana kütlesinden, kolayda örnekleme yöntemiyle veriler toplanmıştır. Kolayda örnekleme yöntemiyle seçilen öğrencilerle yüz yüze anket yapılmıştır. 
Sosyal Yargı Kuramı Perspektifinde Genç Tüketicilerin Davranışsal Niyetlerinin Oluşumunda Illgilenim Düzeylerinin Etkisi

Örneklem grubunun öğrenci olarak belirlenme nedeniyse, akıllı telefonlara olan ilgilenimlerinin yüksek olması beklentisidir. Hazırlanan anket formu, araştırmanın modelini oluşturan değişkenlere ait ifadelerden oluşmaktadır. Örneklemin öğrenci olarak belirlenmesi sebebiyle anket formunda, çok fazla demografik sorulara yer verilmemiştir. Cinsiyet ayrımının incelenebilmesi için cinsiyet sorulmuştur. Sonuç olarak, toplanan 362 anket veri analizinde kullanılmıştır. Çalışma kapsamında kullanılan Yapısal Eşitlik Modellemesinde örneklem büyüklüğü ile ilgili, normal dağılmış bir veri seti için genel olarak 100 sayısının asgari, 200 sayısının da kabul edilebilir sınırlarda olduğu savunulmakta; verilerin normal dağıldığ 1 ve değişkenler arasındaki ilişkilerin nispeten yüksek olduğu modellerde, madde sayısının on katı bir örneklem sayısı elde edildiğinde yeterli olarak kabul edilmektedir (Şimşek, 2007: 55; Çoklu vd., 2014: 110). Yine Klein (2011: 12) de örneklemin madde sayısının 10 katı olması, bu sayının da 200'den az olmaması gerektiği bilgisini çalışmasında doğrulamaktadır. Gelinen nokta itibariyle uygulama için elde edilen 362 adet örneklem sayısının yeterli olduğu düşünülmektedir.

Çalışma kapsamında, tüketicilerin ilgilenimleri Laurent ve Kapferer (1985)'ın algılanan risk, hata olasılığı, sembolik değer, hedonik değer ve ilgi olmak üzere beş boyuttan oluşan Tüketici İlgilenim Profili (CIP) adı verdikleri ilgilenim ölçeği ile ölçülmüştür. Tüketicilerin davranışsal niyetlerinin ölçümünde ise Cronin vd. (2000)'nin 3 (üç) ifadeli ölçeği kullanılmıştır. Çalışma kapsamında kullanılan her iki ölçekte orijinal çalışmalardan alınarak Türkçeye uyarlanmıştır. İlgili ölçeklerin uyarlanmasında ise Brislin (1970)'in önerdiği teknik kullanılmıştır. Bu doğrultuda kullanılan çeviri-geri çeviri yöntemiyle, uzman görüşleri katkısıyla uyarlama gerçekleştirilmiş̧ir. Araştırma kapsamında kullanılan ölçeklerin anlaşılırlığının kontrolü için otuz kişiden oluşan örneklem grubuna ön test yapılmıştır. Sonrasında ölçeklerin kullanıma hazır olduğu görüşüne varılmıştır.5'li Likert tipi ölçek kullanılmıştır (1: Kesinlikle Katılmiyorum, 5: Kesinlikle Katılıyorum).

Genç tüketiciler olarak nitelenen üniversite öğrencilerinden oluşan grubun, akıllı telefonlara yönelik ilgilenimlerinin davranışsal niyet oluşumuna olan etkisinin incelendiği bu araştırmada kullanılan ölçeklerin öncelikle güvenilirlik testi için Cronbach Alfa güvenilirlik katsayıları belirlenmiştir. Açıklayıcı Faktör Analizi (AFA) ve sonrasında Doğrulayıcı Faktör Analizi (DFA) SPSS 22 ve AMOS 23 paket programları yardımıyla yapılmıştır.

\section{Bulgular}

Çalışmaya 186 kadın, 176 erkek olmak üzere toplamda 362 öğrenci katılmıştır. Görüldüğü üzere cinsiyete ilişkin dağılım dengelidir. Araştırmaya katılanların kullandıkları akı1lı telefon markasına yönelik soruya 127 Iphone, 147 Samsung ve 88 diğer cevabı alınmıştır. Örneklemin uygunluğunu test etmek için Kaiser-Meyer-Olkin ve Bartlett'in küresellik testi yapılmıştır. Elde edilen sonuçlar doğrultusunda örneklem üzerinde faktör analizi uygulayabilmek 
için uygun olduğu sonucuna varılmıştır. Açıklayıcı Faktör Analizi sonucunda her bir ölçek grubuna ait faktör yükleri kabul edilen değerlerde elde edilmiştir. Ulaşılan sonuçlar Tablo 1'de sunulmaktadır. Yine faktör analizi esnasında elde edilen Cronbach Alfa değerleri yani iç tutarlılık katsayıları bir diğer ifadeyle güvenilirlik kat sayıları Tablo 1'de gösterilmektedir. Güvenilirlik katsayılarının 0.70 veya daha yüksek olması, yeterli olarak değerlendirilmektedir (Nunnally, 1978). Bu doğrultuda elde edilen değerler de kabul edilir değerler olarak elde edilmiştir.

Tablo 1: Değişkenlere Ait Açıklayıcı Faktör Analizi Tablosu

\begin{tabular}{|c|c|}
\hline $\begin{array}{lr}\text { FAKTÖRLER } & \begin{array}{r}\text { Cronbach Alpha } \\
\text { (Güvenilirlik-İç Tutarlılık Katsayıları) }\end{array}\end{array}$ & $\begin{array}{l}\text { FAKTÖR } \\
\text { YÜKLERİ }\end{array}$ \\
\hline $\begin{aligned} 799 & \end{aligned}$ & \\
\hline İLGİ 1 & ,671 \\
\hline İLGİ 2 & ,782 \\
\hline İLGİ 3 &, 702 \\
\hline Açıklanan varyans yüzdesi $(\%)$ & 71,82 \\
\hline KMO (Kaiser-Meyer-Olkin Measure of Sampling Adequacy) & ,692 \\
\hline Barlett Testi (Bartlett's Test of Sphericity) &, 000 \\
\hline 2.HEDONIK DEĞER & \\
\hline HEDONIK DEĞER 1 & ,839 \\
\hline HEDONIK DEĞER 2 & ,806 \\
\hline HEDONIKK DEĞER 3 & ,790 \\
\hline Açıklanan varyans yüzdesi(\%) & 81,166 \\
\hline KMO (Kaiser-Meyer-Olkin Measure of Sampling Adequacy) &, 740 \\
\hline Barlett Testi (Bartlett's Test of Sphericity) &, 000 \\
\hline 3.SEMBOLIK DEĞER & \\
\hline SEMBOLİK DEĞER 1 &, 850 \\
\hline SEMBOLIK DEĞER 2 & 893 \\
\hline SEMBOLİK DEĞER 3 & ,719 \\
\hline Açıklanan varyans yüzdesi(\%) & 82,051 \\
\hline KMO (Kaiser-Meyer-Olkin Measure of Sampling Adequacy) & ,691 \\
\hline Barlett Testi (Bartlett's Test of Sphericity) &, 000 \\
\hline 4.ALGILANAN RISSK & \\
\hline ALGILANAN RİSK 1 & ,705 \\
\hline ALGILANAN RİSK 2 & ,705 \\
\hline Açıklanan varyans yüzdesi $(\%)$ & 70,508 \\
\hline KMO (Kaiser-Meyer-Olkin Measure of Sampling Adequacy) &, 500 \\
\hline Barlett Testi (Bartlett's Test of Sphericity) &, 000 \\
\hline 5.HATA OLASILIĞI & \\
\hline HATA OLASILIĞI 1 & ,630 \\
\hline HATA OLASILIĞI 2 & ,763 \\
\hline HATA OLASILIĞI 3 &, 737 \\
\hline HATA OLASILIĞI 4 & ,664 \\
\hline Açıklanan varyans yüzdesi(\%) & 69,836 \\
\hline KMO (Kaiser-Meyer-Olkin Measure of Sampling Adequacy) &, 804 \\
\hline Barlett Testi (Bartlett's Test of Sphericity) &, 000 \\
\hline
\end{tabular}


Sosyal Yargı Kuramı Perspektifinde Genç Tüketicilerin Davranışsal Niyetlerinin Oluşumunda Illgilenim Düzeylerinin Etkisi

Tablo 1 Devamı: Değişkenlere Ait Açıklayıcı Faktör Analizi Tablosu 6.DAVRANIŞSAL NIYET

DAVRANISSSAL NIYET 1

DAVRANIŞSAL NIYET 2

DAVRANIŞSAL NIYET 3

Açıklanan varyans yüzdesi(\%)

KMO (Kaiser-Meyer-Olkin Measure of Sampling Adequacy)

Barlett Testi (Bartlett's Test of Sphericity)

, 853

İlgilenimin boyutlarından oluşan ölçeklerin örneklem açısından geçerliliğini test etmek amaciyla doğrulayıcı faktör analizi yapılmıştır. Doğrulayıcı faktör analizi yapılırken AMOS paket programı kullanılmıştır. Doğrulayıcı faktör analizi path diyagramı Şekil 2'de gösterilmektedir.

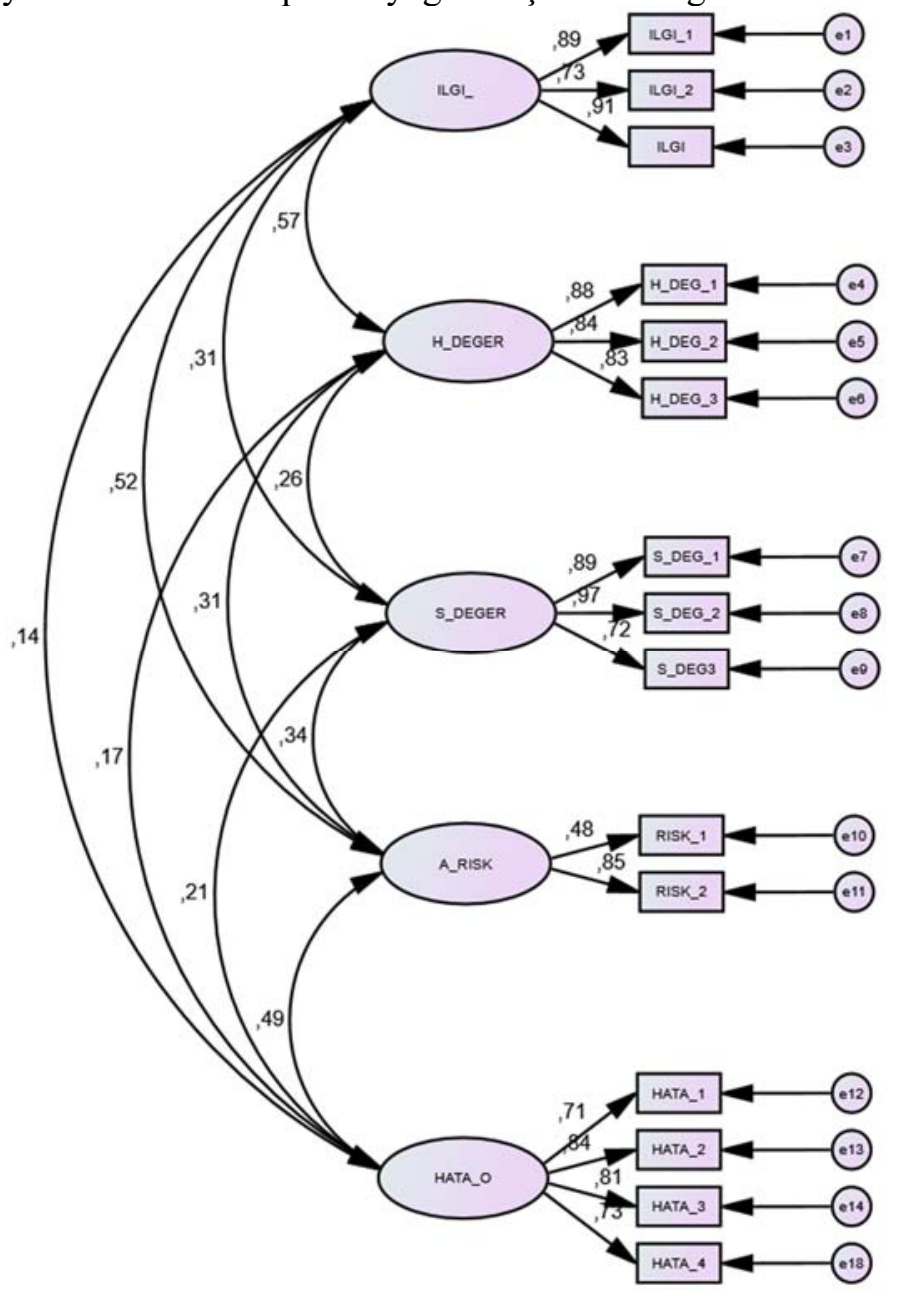

Şekil 2: Doğrulayıcı Faktör Analizinin Gösterimi 
Yukarıda path diyagramında sunulan DFA sonuçları Tablo 2'de ayrıntılı olarak verilmektedir. Tablo 2'de sunulan DFA sonuçları incelendiğinde gözlenen değişkenlere ait standartlaştırılmış regresyon katsayıları, standart hata değerleri, $t$ değerleri $(t>1.96)$ ve $p$ değerleri $(p<0.05)$ istatiksel olarak modeli anlamlı kılan değerlerdir.

Tablo 2: Doğrulayıcı Faktör Analizi Sonuçları

\begin{tabular}{|c|c|c|c|c|c|}
\hline $\begin{array}{c}\text { Gizil } \\
\text { Değişkenler }\end{array}$ & $\begin{array}{c}\text { Gözlenen } \\
\text { Değişkenler }\end{array}$ & $\begin{array}{c}\text { Standartlaştırılmış } \\
\text { 及 Değerleri }\end{array}$ & $\begin{array}{l}\text { Standart } \\
\text { Hata }\end{array}$ & $t$ & $p$ \\
\hline \multirow{3}{*}{ İLGí } & İLGİ_1 & 0,887 & & & \\
\hline & İLGİ_2 & 0,725 & 0,044 & 16,205 & **** \\
\hline & İLGİ_3 & 0,908 & 0,020 & 21,973 & $* * *$ \\
\hline \multirow{3}{*}{$\begin{array}{l}\text { HEDONIK } \\
\text { DEĞER }\end{array}$} & H_DEGER_1 & 0,877 & & & \\
\hline & $\mathrm{H}_{-} \mathrm{DEGER}_{-}^{-} 2$ & 0,837 & 0,055 & 19,007 & *** \\
\hline & $\mathrm{H}^{-}$DEGER 3 & 0,830 & 0,051 & 18,829 & $* * *$ \\
\hline \multirow{3}{*}{$\begin{array}{l}\text { SEMBOLIKK } \\
\text { DEĞER }\end{array}$} & S_DEGER_1 & 0,889 & & & \\
\hline & S_DEGER_2 & 0,966 & 0,043 & 24,364 & *** \\
\hline & S_DEGER_3 & 0,717 & 0,046 & 16,694 & *** \\
\hline \multirow{2}{*}{$\begin{array}{l}\text { ALGILANAN } \\
\text { RISK }\end{array}$} & A_RISK_1 & 0,481 & & & \\
\hline & $\mathrm{A}^{-} \mathrm{RISK}-2$ & 0,854 & 0,052 & 10,422 & *** \\
\hline \multirow{4}{*}{$\begin{array}{c}\text { HATA } \\
\text { OLASILIĞI }\end{array}$} & HATA_O_1 & 0,708 & & & \\
\hline & HATA_O_2 & 0,837 & 0,076 & 14,066 & *** \\
\hline & HATA_O-3 & 0,815 & 0,083 & 13,813 & $* * *$ \\
\hline & HATA- ${ }^{-} 4$ & 0,734 & 0,084 & 12,631 & $* * *$ \\
\hline
\end{tabular}

Tablo 3'ten görülebileceği üzere DFA sonucu tüm değişkenlere ait uyum iyiliği değerlerinin kabul edilebilir düzeyde olduğu sonucuna ulaşılmıştır. Tüm bu sonuçlar doğrultusunda ölçülen bu yapısal modelin kabul edilebilirliği ortaya koyulmuştur. Literatürde kabul edilen, uyum iyiliği indekslerine ait değerler ve DFA sonucu elde edilen değerler Tablo 3'te sunulmaktadır.

Tablo 3: DFA Sonucu Elde Edilen Uyum İyiliği Değerlerinin Gösterimi (Kaynak: Meydan ve Şeşen, 2011: 37).

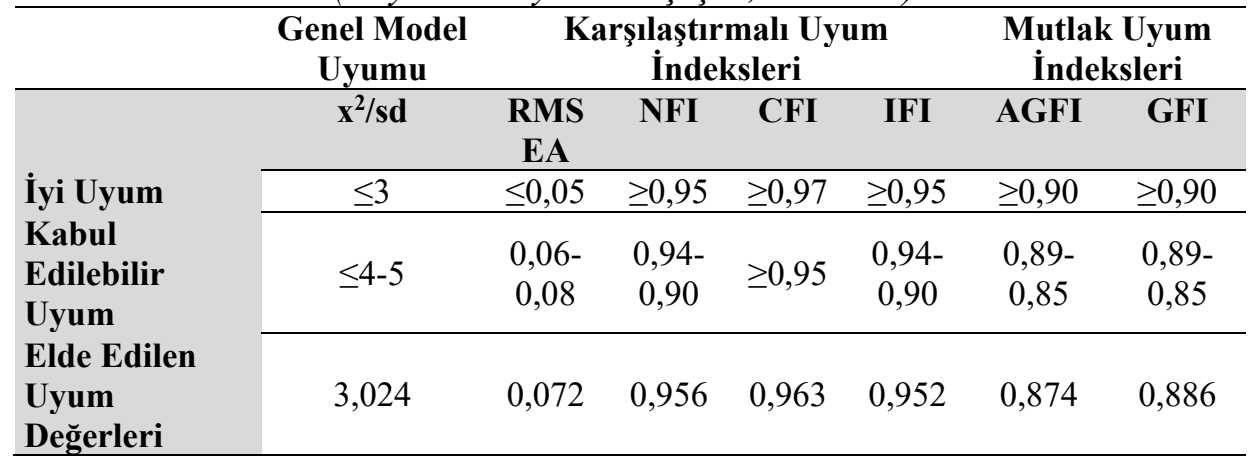

$\mathbf{x}^{\mathbf{2}}$ : Chi-Square (Ki-Kare); sd: Degree of Freedom (Serbestlik Derecesi); RMSEA: Root Mean Square Error of Approximation (Yaklaşık Hataların Ortalama Karekökü); NFI: Normed Fit İndeksi (Normlaştırılmış Uyum İndeksleri); CFI: Comparative Fit Index (Karşılaştırmalı Uyum 
Sosyal Yargı Kuramı Perspektifinde Genç Tüketicilerin Davranışsal Niyetlerinin Oluşumunda Illgilenim Düzeylerinin Etkisi

İndeksi); IFI: Incremantal Fit Index (Artırmalı Uyum İndeksi); AGFI: Adjusment Goodness of Fit Index ( Düzeltilmiş İyilik Uyum İndeksi; GFI: Goodness Of Fit Index (İyilik Uyum İndeksi).

Araştırma kapsamında, ele alınan ölçeklerin geçerlilik ve güvenilirlik testinin ardından, yapı geçerliliği ve yapı güvenilirliği testinin uygulanması da gereklidir (Hair vd., 2014a: 619). Örtük değişkene yüklenen gözlenen değişkenlerin içsel güvenilirliğinin tespiti için kullanılan yapı güvenilirliğinin 0.70 ya da daha yüksek bir değer alması gereklidir (Hair vd., 2014a: 605). Yap1 geçerliliğinin sağlanabilmesi için ise birleşme ve ayrım geçerliliği değerlerine bakılmalıdır (Hair vd., 2014a: 619). Birleşme geçerliliğinin sağlanabilmesi için Ortalama Açıklanan Varyans (AVE) değerlerinin 0.50 ya da daha üstünde değer alması gereklidir (Hair vd., 2014a: 605).

İlgi, hedonik değer, sembolik değer, algılana risk, hata olasıllı̆̆ ve davranışsal niyet kavramlarını ölçen altı değişken esas alınarak araştırma modeli oluşturulmuştur. Her bir değişkenin farklı bir kavramı ölçtügünün kontrolünü sağlamak için ise ayrım geçerliliğinin incelenmesi gereklidir. Ayrım geçerliliğinin sağlanabilmesi için ise AVE değerlerinin kareköklerinin, ilgili değişkenin diğer değişkenlerle olan korelasyon değerinden yüksek olması gereklidir. Diğer bir ifadeyle değişkenler arasındaki korelasyonların karelerinin, AVE değerlerinden düşük olması, ayrım geçerliliği için gerekmektedir (Hair vd., 2014a: 605). Ulaşılan tüm değerler bir arada değerlendirildiğinde, ölçüm modeli için yap1 geçerliliği ve yap1 güvenilirliği sağlandığ sonucuna varılmıştır. Söz konusu değerler Tablo 4'te sunulmaktadır.

Tablo 4: Yapı güvenilirliği, ayrım geçerliliği ve birleșme geçerliliği

\begin{tabular}{lcccccccrr}
\hline Değișkenler & CR & AVE & $\sqrt{\boldsymbol{A} \boldsymbol{V} \boldsymbol{E}}$ & $\mathbf{1}$ & $\mathbf{2}$ & $\mathbf{3}$ & $\mathbf{4}$ & $\mathbf{5}$ & $\mathbf{6}$ \\
\hline 1.İlgi & 0,76 & 0,52 & 0,72 & & & & & & \\
2.Hedonik Değer & 0,85 & 0,66 & 0,81 & 0,43 & & & & & \\
3.Sembolik Değer & 0,86 & 0,68 & 0,82 & 0,24 & 0,25 & & & & \\
4.Algılanan Risk & 0,66 & 0,51 & 0,71 & 0,36 & 0,20 & 0,31 & & & \\
5.Hata Olasılığı & 0,79 & 0,52 & 0,71 & 0,14 & 0,14 & 0,18 & 0,32 & & \\
6.Davranışsal & 0,82 & 0,61 & 0,78 & 0,10 & 0,11 & 0,14 & 0,18 & 0,12 & \\
Niyet & & & & & & & & & \\
\hline
\end{tabular}

Tüm korelasyon değerleri $\mathrm{p}<0,05$ düzeyinde anlamlıdır.

CR: Yap1 Güvenilirliği (Composite Reliability)

AVE: Ortalama Açıklanan Varyans (Avarage Variance Extracted)

İlgilenimin boyutlarının davranışsal niyete olan etkilerinin testi için ise basit doğrusal regresyon analizi kullanılmıştır. $\mathrm{Bu}$ analizden elde edilen sonuçlar ise Tablo 5'te gösterilmektedir. 
Tablo 5: Ilgilenimin Boyutlarının Davranışsal Niyete Olan Etkisinde Regresyon Analiz Sonuçlarının Gösterimi

\begin{tabular}{lccc}
\hline \multicolumn{1}{c}{ Model } & Standardize $\boldsymbol{\beta}$ & Standart Hata & p \\
\hline İlgi-Davranışsal Niyet & 0,47 & 0,063 & $<0,05$ \\
Hedonik Değer-Davranısssal Niyet & 0,44 & 0,061 & $<0,05$ \\
Sembolik Değer-Davranışsal Niyet & 0,38 & 0,093 & $<0,05$ \\
Algılanan Risk-Davranışsal Niyet &,- 31 & 0,022 & $<0,05$ \\
Hata Olasılığı-Davranışsal Niyet &,- 37 & 0,016 & $<0,05$ \\
\hline
\end{tabular}

Tablo 5 incelendiğinde, ilginin davranışsal niyet $(\beta=0,47 ; \mathrm{p}<0,05)$; hedonik değerin davranışsal niyet $(\beta=0,44 ; \quad p<0,05)$; sembolik değerin davranışsal niyet $(\beta=0,38 ; \mathrm{p}<0,05)$; algılanan riskin davranışsal niyet $(\beta=-0,31$; $\mathrm{p}<0,05)$; hata olasılığının davranışsal niyet $(\beta=-0,37 ; \mathrm{p}<0,05)$ üzerinde istatistiksel olarak anlamlı bir etkiye sahip olduğu tespit edilmiştir. $\mathrm{Bu}$ doğrultuda çalışma kapsamında öngörülen tüm hipotezler kabul edilmiştir.

\section{Sonuç ve Öneriler}

Bireylerin tutum ve davranışlarını analiz eden çalışmalarda ilgilenim düzeylerinin incelenme ihtiyacı, tüketici tutum ve davranışlarının incelenmesinde de ilgilenim düzeylerinin incelenmesi gerekliliğine yöneltmektedir. Tüketicilerin ilgilenim düzeylerinin aynı olması beklenmeyen bir durumdur. Tüketici davranışlarının bireylerin ürüne verdikleri ilgi ve önem düzeyine göre farklılaşması beklenmektedir. Ajzen ve Fishbein (1977)'e göre, tutumlar bireylerin davranışlarını tahmin edebilmede önemli faktörlerden birisidir. Bireylerin tutumları ise davranışsal niyetlerini şekillendirmektedir. $\mathrm{Bu}$ çalışmada da tutum yerine davranışsal niyete odaklanılarak davranışa en yakın sonuçlara ulaşılması amaçlanmıştır.

Tüketici davranışlarında iki önemli kavram, ilgilenim ve davranışsal niyettir. Bu çalışma iki faktör arasındaki ilişkiyi desteklemiştir. Tüketicilerin davranışlarının oluşumunda ilgilenim düzeylerinin etkisinin olacağından hareketle tasarlanan bu araştırma sonucunda, tüketicilerin ilgilenim düzeyleri yükseldikçe davranışsal niyet oluşumlarının güçleneceği sonucuna ulaştırmıştır.

Araştırma bulguları, davranışsal niyet oluşumunun tüketicilerin ilgilenimlerinden etkilendiğini ortaya koymaktadır. Tüketicilerin ilgilenim düzeylerindeki artış, davranış öncüsü olan niyetlerinin belirlenmesinde önem kazanmaktadır. Araştırmadan elde edilen sonuçlara göre faktörler arasında etki var; ancak bu etki çok yüksek düzeyde gerçekleşmemiştir. Buradan hareketle tüketicilerin davranışsal niyetlerinin oluşumunda tatmin, kalite güven gibi diğer faktörlerin etkisinin var olduğu şeklinde bir yorumlama yapılabilir. Ayrıca tüketicilerin ilgilenim düzeylerinin davranışsal niyetlerine olan etkisinin incelendiği bu çalışmada ilgilenim değişkeninin literatürde yaygın olarak yer verilen beş boyutlu haliyle davranışsal niyet oluşumundaki etkileri ayrı ayrı 
Sosyal Yargı Kuramı Perspektifinde Genç Tüketicilerin Davranışsal Niyetlerinin Oluşumunda Illgilenim Düzeylerinin Etkisi

ölçülmüştür. Yapılan analizlerin ardından ilgilenimin boyutlarından olan ilgi, hedonik değer ve sembolik değerin pozitif yönde; algılanan risk ve hata olasılığ boyutlarının ise negatif yönde tüketicilerin niyetlerinin şekillenmesinde en fazla etkiyi gösterdiği ortaya çıkmıştır.

Çalışmanın uygulama bölümünde kullanılan akıllı telefon, yüksek ilgilenim düzeyli bir üründür. Uygulayıcılar, tüketicilerin satın alma işlemlerinde etkili olmak istiyorlarsa, bu çalışmada alt boyutlarıyla birlikte ele alınan tüketici ilgileniminin, davranışsal niyeti oluşturmadaki etkisi doğrultusunda hareket etmelilerdir. Genç tüketiciler ve akıllı telefon özelinde gerçekleştirilen bu çalışma ile ilgi, hedonik değer ve sembolik değerin pozitif; algılanan risk ve hata olasılığı ile negatif doğrultuda davranışsal niyete olan etkilerini göstermektedir. Akıllı telefon pazarında, uygulayıcıların ürünlerine yönelik algılanan risk düzeyi ve hata olasılığını düşürerek; genç tüketicilerin ilgi, hedonik değer ve sembolik değer algılarını artıracak doğrultuda pazarlama stratejileri oluşturmalarının gerekli olduğu çalışma sonuçlarıyla desteklenmiştir.

$\mathrm{Bu}$ çalışma literatüre ve uygulamaya dönük katkılarının yanında bazı kısıtlara da sahiptir. Kolayda örneklem yöntemiyle örneklem seçiminin yapılmış olması çalışmanın kısıtları arasındadır. Farklı örneklem gruplarında da test edilmesi ile genellenebilirlikten uzak olan sonuçları biraz daha genelleştirebilmek mümkündür. Gelecekteki araştırmalarda, tüketicilerin ilgilenim düzeylerinin sürekli ilgilenim mi yoksa durumsal ilgilenim kaynaklı $\mathrm{m} 1$ olduğu ayrımı yapılarak ölçülmesi mümkündür. İnternet ortamında, özellikle sosyal medya ortamında tüketicilerin ilgilenim duydukları ürünleri araştırmaları ve ardından o ürüne dair hatırlatıcı reklamların tüketicilerin karşılarına çıarılması da ilgilenime dönük reklam sergilemenin güzel örnekleridir. $\mathrm{Bu}$ doğrultuda ileride yapılacak çalışmalarda bunun da ölçülebilmesi, ilgilenimin niyet oluşumundaki etkisini reklamlar üzerinden de incelenmesini mümkün k1lmaktadır.

\section{Kaynaklar}

Ajzen, I. ve Fishbein, M. (1977). Attitude-Behavior Relations: A Theoretical Analysis and Review of Empirical Research, Psychological Bulletin. 84(5), 888-918.

Arbore, A., Soscia, I. ve Bagozzi, R. P. (2014). The Role of Signaling Identity in the Adoption of Personal Technologies, Journal of the Association for Information Systems, 15(2), 86-110.

Bai, B., Law, R. ve Wen, I. (2008). The Impact of Website Quality on Customer Satisfaction and Purchase Intentions: Evidence from Chinese Online Visitors, International Journal of Hospitality Management, 27(3), 391402.

Baysal, A. C. (1981). Sosyal Psikolojide Tutumlar, İstanbul Üniversitesi Işsletme Fakültesi Dergisi, 10(1), 121-138. 
Brehmer, B. (1988). The Development of Social Judgment Theory, Advances in Psychology, 54, 13-40.

Brislin, R.W. (1970). Back-Translation for Cross-Cultural Research, Journal of Cross-Cultural Psychology, 1(3), 185-216.

Cooksey, R. W. (1996). The Methodology of Social Judgement Theory, Thinking \& Reasoning, 2(2-3), 141-174.

Çakır, V. (2007). Tüketici İlgilenimini Ölçmek. Selçuk Üniversitesi, İletişsim Fakültesi, 4(4), 163-180.

Çokluk, Ö., Şekercioğlu, G. ve Büyüköztürk, Ş. (2014), Sosyal Bilimler İçin Çok Değişkenli İstatistik: SPSS ve LISREL Uygulamaları, Üçüncü Bask1, Pegem Akademi, Ankara.

Davis, F. D. (1989) "Perceived Usefulness, Perceived Ease of Use, and User Acceptance of Information Technology", MIS Quarterly, 13(3), 319-340.

Dhir, K. S. (1987). Analysis of Consumer Behaviour in the Hospitality Industry: An Application of Social Judgement Theory, International Journal of Hospitality Management, 6(3), 149-160.

Eastman, J. K., Iyer, R., Liao-Troth, S., Williams, D. F. ve Griffin, M. (2014). The Role of Involvement on Millennials' Mobile Technology Behaviors: The Moderating Impact of Status Consumption, Innovation, and Opinion Leadership, Journal of Marketing Theory and Practice, 22(4), 455-470.

Fishbein M. ve Ajzen, I. (1974). Attitudes Toward Objects as Predictors of Single and Multiple Behavioral Criteria, Psychology Review, 81(1), 5974.

Fishbein, M. (Ed.). (1967). Readings in Attitude Theory and Measurement, Wiley, New York.

Fishbein, M. ve Ajzen, I. (1975). Belief, Attitude, Intention and Behavior: An Introduction to Theory and Research, http://people.umass.edu/aizen/f\&a1975.html

Erişim Tarihi: 12.11.2016.

Hair, J.F. Jr., Black, W.C., Babin, B.J.,ve Anderson, R.E. (2014a). Multivariate Data Analysis (7th Edition). New Jersey: Pearson Prentice Hall.

Hammond, K.R., Stewart, T.R., Brehmer, B. ve Steinmann, D.O. (1975), Social Judgment Theory, Academic Press, New York.

Higgie A. R., ve Feick F.L. (1989) . Enduring Involvement: Conceptual and Measurement Issues, Advances in Consumer Research, 16, 690-696.

Jain, K., ve Srinivasan, N. (1990). An Empirical Assessment of Multiple Operationalizations of Involvement, Advances in Consumer Research, 17, 594-602.

Kaur, G., ve Gupta, S. (2012). Consumers' Behavioral Intentions Toward SelfService Technology in the Emerging Markets, Journal of Global Marketing, 25(5), 241-261. 
Sosyal Yargı Kuramı Perspektifinde Genç Tüketicilerin Davranışsal Niyetlerinin Oluşumunda Ilgilenim Düzeylerinin Etkisi

Kline, R. B. (2011), Methodology in the Social Sciences: Principles and Practice of Structural Equation Modeling, Third Edition, The Guilford Press, New York.

Laurent, G. ve Kapferer, J. N. (1985). Measuring Consumer Involvement Profiles, Journal of Marketing Research, 22, 41-53.

Leckie, C., Nyadzayo, M. W. ve Johnson, L. W. (2016). Antecedents of Consumer Brand Engagement and Brand Loyalty, Journal of Marketing Management, 32(5-6), 558-578.

Lin, J. S. C. ve Hsieh, P. L. (2007). The Influence of Technology Readiness on Satisfaction and Behavioral Intentions toward Self-service Technologies, Computers in Human Behavior, 23(3), 1597-1615.

López, T. S., Ranasinghe, D. C., Patkai, B. ve McFarlane, D. (2011). Taxonomy, Technology and Applications of Smart Objects, Information Systems Frontiers, 13(2), 281-300.

McQuarrie, E. F. ve Munson, J. M. (1986). The Zaichkowsky Personal Involvement Inventory: Modification and Extension, Advances in Consumer Research, 14, 36-40.

Meydan, C.H. ve Şeşen, H. (2011). Yapısal Eşitlik Modellemesi AMOS Uygulamaları, İkinci Bask1, Detay Yayınc1lı, Ankara.

Michaelidou, N. ve Dibb, S. (2008). Consumer Involvement: a New Perspective, The Marketing Review, 8(1), 83-99.

Mittal, B., (1989). Measuring Purchase-decision Involvement, Psychology and Marketing, 6(2), 147-162.

Mittal, V. ve Kamakura, W.A. (2001). Satisfaction, Repurchase Intent, and Repurchase Behavior: Investigating the Moderating Effect of Customer Characteristics, Journal of Marketing Research, 38, 131-142.

Montano, D. E. ve Kasprzyk, D. (2008). Theory of Planned Behavior, and the Integrated Behavioral Model, Health Behavior and Health Education: Theory, Research, and Practice. San Francisco, CA: Jossey-Bass, 67-96.

Nunnally, J. C. (1978). Psychometric Theory, Second Edition, McGraw-Hall, New York.

Ostrom, T. M. ve Brock, T. C. (1968). A Cognitive Model of Attitudinal Involvement, Theories of Cognitive Consistency: A Sourcebook, 373-383.

Özbek, V. ve Külahlı, A. (2016). Tüketicilerin İlgilenim, Memnuniyet ve Sadakat Düzeyleri Cinsiyete Göre Değişmekte midir?, Business \& Management Studies: An International Journal, 4(3), 316-340.

Park, C. W. ve Young, S. M. (1983). Types and Levels of Involvement and Brand Attitude Formation, Advances in Consumer Research, 10, 320324.

Sherif, C. W., Kelly, M., Rodgers Jr, H. L., Sarup, G. ve Tittler, B. I. (1973). Personal Involvement, Social Judgment, and Action, Journal of Personality and Social Psychology, 27(3), 311-328. 
Sherif, M. ve Sherif, C. W. (1967). Attitude As the Individual's Own Categories: The Social Judgment-Involvement Approach to Attitude and Attitude Change, New York: Wiley,105-139.

Sığındı, T. ve Kavak, B. (2015). Satın Alma Niyetinin Öngörüsünde Planlı Davranış Modeli'nin Farklı Ürün Sınıfları İçin Denenmesi, Anadolu Üniversitesi Sosyal Bilimler Dergisi, 15(2), 111-128.

Solomon, M., Bamossy, G., Askeegard, S. ve Hogg M.K. (2006). Consumer Behaviour, A European Perspective, Third Edition, Prentice Hall, New York.

Şimşek, Ö. F. (2007). Yapısal Eşitlik Modellemesine Giriş, Ekinoks Yayınları, Ankara.

Ulusu, Y. (2016). İlgilenim, Öneri Dergisi, 12(45), 569-586.

Zaichkowsky, J. L. (1985). Measuring the Involvement Construct, Journal of Consumer Research, 12(3), 341-352.

Zaichkowsky, J. L. (1994). The Personal Involvement Inventory: Reduction, Revision, and Application to Advertising, Journal of Advertising, 23(4), 59-70.

Zeithaml, V. A., Berry, L. L. ve Parasuraman, A. (1996). The Behavioral Consequences of Service Quality, The Journal of Marketing, 60(2), 3146. 